\title{
Keragaan In Vitro dan In Vivo Hibrida Somatik antara Solanum melongena cv. Dourga dengan Solanum torvum Sw.
}

\author{
Agus Joko Santoso ${ }^{1 *}$, Ali Husni², dan Agus Purwito ${ }^{1}$ \\ ${ }^{1}$ Departemen Agronomi dan Hortikultura, Fakultas Pertanian, Institut Pertanian Bogor \\ (Bogor Agricultural University), J1. Meranti, Kampus IPB Darmaga, Bogor 16680, Indonesia \\ Telp.\&Faks.62-251-8629353 e-mail agronipb@indo.net.id \\ ${ }^{2}$ Kelompok Peneliti Biologi Sel dan Jaringan, BB-Biogen, Jl. Tentara Pelajar 3A, Bogor 16111, Indonesia \\ Telp.0251-8337975, Faks.0251-8338820e-mail borif@indo.net.id \\ *Penulis untuk korespondensi: aa.agus.js@gmail.com
}

Disetujui 24 Desember 2013/ Published Online 10 Januari 2014

\begin{abstract}
Eggplant is host to many kind ofdiseases. One approach to improve resistancecharacters is by combining the eggplant cultivars with theirwild relatives through fusion protopas. The research was conducted to study the variability of in vitro and in vivo performance of the somatic hybrids between Solanum melongena cv. Dourga and Solanum torvum Sw. This study used seven clones, Solanum melongena cv. Dourga, Solanum torvum Sw., and fiveclones of somatic hybrids (SMST1, SMST2, SMST3, SMST4, and SMST5). The research was arranged based oncompletely randomized design using single factor. The variables measured were plant height, number of leaves, leaf length, petiole length, number of roots, root length, number of stem segment, stem color, petiole color, the number of spines on the leaf surface, and leaf blade lobing. The results showed that in in vitro conditions, the growth of Solanum torvum Sw. was significantly more vigor compare to the other five somatic hybrid clones. Clones SMST1, SMST2, and SMST4 were grewbetter than that of clone SMST3 and SMST5. In in vivo condition, the clones tested had a similarity with Solanum torvum $S w$.
\end{abstract}

Keywords: phenotypic variability, protoplast fusion, turkey berry, white eggplant.

\section{ABSTRAK}

Terung adalah tanaman yang mudah terserang oleh banyak jenis penyakit. Salah satu usaha yang dapat dilakukan untuk meningkatkan ketahanan terhadap penyakit tersebutadalah dengan mengintroduksi sifat ketahanandari kerabat liarnya melalui fusi protopas. Penelitian ini dilakukan untuk mempelajari keragaan in vitro dan in vivo hibrida somatik hasil fusi protoplas Solanum melongena cv. Dourga dengan Solanum torvum $S w$. Penelitian ini merupakan penelitian faktor tunggal dengan tujuh taraf klon, yaitu Solanum melongena cv. Dourga (SM), Solanum torvum Sw. (ST), dan 5 klon hibrida somatik (SMST1, SMST2, SMST3, SMST4, and SMST5) yang disusun menggunakan Rancangan Acak Lengkap (RAL). Peubah yang diamati antara lain tinggi tanaman, jumlah daun, panjang daun, panjang tangkai daun, jumlah akar, panjang akar, jumlah buku, warna batang, warna tangkai daun, jumlah duri pada permukaan daun, dan bentuk lobus daun. Pada kondisi in vitro, pertumbuhan Solanum torvum Sw. berbeda sangat nyata dengan kelima klon hibrida somatik. Klon SMST1, SMST2, dan SMST4 menunjukkan pertumbuhan yang lebih baik dari klon SMST3 dan SMST5. Pada kondisi in vivo, klon-klon yang diuji memiliki kekerabatan yang lebih dekat dengan Solanum torvum $\mathrm{Sw}$.

Kata kunci: keragaan fenotipik, terung pipit, takokak, terung putih.

\section{PENDAHULUAN}

Terung (Solanum melongena L.) adalah salah satu tanaman komersial penting yang dimanfaatkan buahnya untuk dikonsumsi sebagai sayuran. Terung termasuk tanaman herba tegak dan berkayu dengan tinggi antara 0.3 sampai 1.5 meter. Tanaman ini berasal dari India dan saat ini telah tersebar di daerah tropis lainnya (Wijayakusuma, 2004). Salah satu penyakit yang 
menjadi permasalahan serius pada tanaman terung di daerah tropis adalah penyakit layu bakteri yang disebabkan oleh Rastolnia solanacearum (Kallo, 1986). Penyakit ini dapat menular melalui tanah yang terkontaminasi, peralatan, air, serangga, atau melalui benih terinfeksi dan persemaian (Tahat dan Sijam, 2010). Cara yang paling efektif dan efisien untuk menanggulangi penyakit tersebut adalah dengan menggunakan varietas tahan (Husniet al., 2004). Akan tetapi, sumber ketahanan umumnya terdapat pada spesies liar seperti $S$. torvum Sw. (Kallo, 1986; Budi, 2002; Husniet al., 2004), sehingga pemindahan sifat sulit dilakukan dengan persilangan konvensional karena inkompatibilitas yang tinggi (Collonieret al., 2001). Oleh karena itu, salah satu teknik yang dapat dilakukan untuk memindahkan sumber ketahanan ini adalah dengan teknik fusi protoplas (Husniet al., 2004).

Beberapa penelitian tentang fusi protoplas $S$. melongena dengan kerabat liarnya untuk menghasilkan hibrida yang resistan terhadap penyakit layu bakteri telah dilakukan. Hasil penelitian Saputra (2002) membuktikan bahwa fusi protoplas $S$. melongena $\mathrm{L}$. dengan $S$. aethiopicum menghasilkan hibrida somatik yang lebih tahan dari kedua tetuanya. Budi (2002) telah melakukan pengujian terhadap 21 nomor tanaman hasil fusi protoplas $S$. melongena cv. Dourga dengan $S$. torvum $\mathrm{CN} 2$ pada dua tahap percobaan dan menemukan tiga nomor tanaman yang konsisten ketahanannya terhadap $R$. Solanacearum. Mariska dan Husni (2006) telah melakukan fusi protoplas terung dengan takokak namun menghasilkan hibrida hasil fusi yang tidak dapat menghasilkan buah.Meskipun telah ditemukan hibrida somatik hasil fusi protoplas $S$. melongena $\mathrm{L}$. dengan $S$. torvum $\mathrm{Sw}$. yang tahan terhadap penyakit layu bakteri, penelitian lanjutan untuk mengetahui keragaan yang dibawa oleh hibrida somatik perlu dilakukan.

\section{BAHAN DAN METODE}

Penelitian ini dilaksanakan pada bulan April sampai Juli 2012 di laboratorium in vitro Kelompok Peneliti Biologi Sel dan Jaringan Balai Besar Penelitian dan Pengembangan Bioteknologi dan Sumberdaya Genetik Pertanian (BB Biogen), Bogor dan di Greenhouse Kebun Percobaan Cikabayan, Institut Pertanian Bogor.

Bahan tanaman terung yang digunakan dalam percobaan in vitro adalah lima klon hibrida somatikdan dua kultivar tetua. Klon hibrida somatik tersebut merupakan koleksi in vitro di
Balai Besar Penelitian dan Pengembangan Bioteknologi dan Sumberdaya genetik Pertanian (BB Biogen). Bahan tanaman yang digunakan dalam percobaan in vivo adalah planlet yang dihasilkan dari percobaan in vitro. Media yang digunakan dalam kultur in vitro adalah MS (Murashige dan Skoog 1962) dengan penambahan vitamin MW (Morel dan Wetmore 1951), $30 \mathrm{~g}$ sukrosa, dan $7 \mathrm{~g}$ agar. Media tanam yang digunakan ketika aklimatisasi adalah campuran tanah dan pupuk organik dengan komposisi $1: 1$ yang telah disterilisasi pada suhu $121^{\circ} \mathrm{C}$ selama empat jam. Media tanam yang digunakan pada percobaan in vivo terdiri dari campuran tanah dan pupuk organik dengan komposisi $2: 1$. Untuk pengendalian bakteri dan jamur digunakan bakterisida Agrept dan fungisida antracol. Pupuk buatan yang digunakan adalah Urea, SP 36, dan $\mathrm{KCl}$. Peralatan yang digunakan dalam percobaan in vitro adalah laminar air flow dan alat tanam kultur jaringan pada umumnya. Peralatan yang digunakan dalam percobaan in vivo adalah greenhouse, cangkul, polibag ukuran $20 \mathrm{~cm}$ x 25 $\mathrm{cm}$, dan sungkup plastik transparan.

Rancangan yang digunakan dalam penelitian ini adalah Rancangan Acak Lengkap (RAL) faktor tunggal. Percobaan dilakukan dengan tujuh taraf perlakuan yang terdiri dari $S$. melongena cv. Dourga dan S. torvum Sw. sebagai tetua, serta lima nomor hibrida somatik antaraS. melongena cv. Dourga dengan $S$. torvum $\mathrm{Sw}$. (SMST1, SMST2, SMST3, SMST4, SMST5). Pada percobaan in vitro, setiap perlakuan diulang sebanyak sepuluh kali dengan satu tabung reaksi untuk setiap satuan percobaan, sehingga dibutuhkan masing-masing sepuluh eksplan untuk setiap perlakuan. Seluruh eksplan ditanam pada media MS + Vit. MW + 30 g sukrosa +7 g agar. Pada percobaan in vivo, setiap perlakuan diulang sepuluh kali dengan satu polibag $5 \mathrm{~kg}$ untuk setiap satuan percobaan, sehingga dibutuhkan masingmasing sepuluh polibag S. melongena cv. Dourga, S. torvum Sw., dan lima nomor hibrida somatik.

Pengamatan pada percobaan in vitro dimulai pada 1 MST sampai 5 MST. Adapun peubah yang diamati antara lain: tinggi tanaman, diukur dari tempat munculnya tunas sampai ujung tunas apikal; jumlah daun, dihitung pada seluruh bagian tanaman yang telah tumbuh sempurna; jumlah akar; panjang akar terpanjang; jumlah buku; dan warna daun.Pengamatan pada percobaan in vivo dimulai pada 1 MST sampai 5 MST. Peubah yang diamati pada pengamatan kuantitatif antara lain: tinggi tanaman, diukur dari permukaan tanah hingga ujung tunas apikal; jumlah daun, dihitung 
pada seluruh bagian tanaman yang telah tumbuh sempurna; panjang daun, diukur dari pangkal hingga ujung daun; panjang tangkai daun, diukur dari ketiak daun hingga pangkal daun; dan jumlah duri pada permukaan atas daun. Pada pengamatan kualitatif, peubah yang diamati antara lain: warna batang dan tangkai daun; bentuk lobus daun; dan duri pada batang.Data kuantitatif yang diperoleh diuji dengan uji $\mathrm{F}$ dan hasil sidik ragam yang menunjukkan perbedaan yang nyata dari pengaruh perlakuan diuji lebih lanjut dengan Duncan Multiple Range Test (DMRT). Data kualitatif yang diperoleh dianalisis menggunakan analisis gerombol.

\section{HASIL DAN PEMBAHASAN}

\section{Keragaan Fenotipik Tanaman in Vitro}

Tabel 1. Rekapitulasi uji F dari peubah vegetatif yang diamati pada keragaan in vitro klonterung yang diuji pada umur 1-5 MST

\begin{tabular}{llllll}
\hline \multirow{2}{*}{ Peubah vegetatif } & \multicolumn{5}{c}{ Klon } \\
\cline { 2 - 6 } & $1 \mathrm{MST}$ & $2 \mathrm{MST}$ & 3 MST & 4 MST & 5 MST \\
\hline Tinggi tanaman & $* *$ & $* *$ & $* *$ & $* *$ & $* *$ \\
Jumlah daun & $* *$ & $* *$ & $* *$ & $* *$ & $* *$ \\
Jumlah akar & $* *$ & $* *$ & $* *$ & $* *$ & $* *$ \\
Panjang akar terpanjang & $* *$ & $* *$ & $* *$ & $* *$ & $* *$ \\
Jumlah buku & - & - & - & - & $* *$ \\
\hline
\end{tabular}

Ket.: **: berpengaruh sangat nyata pada uji $\mathrm{F}$ taraf $1 \%,-$ : pengamatan tidak dilakukan, MST : minggu setelah tanam.

Tabel 2. Rata-rata tinggi tanaman terungpada keragaan in vitro klon yang diuji pada umur 1-5 MST

\begin{tabular}{llllll}
\hline Klon & \multicolumn{5}{c}{ Tinggi tanaman $(\mathrm{cm})$} \\
\cline { 2 - 6 } & $1 \mathrm{MST}$ & $2 \mathrm{MST}$ & $3 \mathrm{MST}$ & $4 \mathrm{MST}$ & $5 \mathrm{MST}$ \\
\hline S. melongena cv. Dourga & $0.12 \mathrm{a}$ & $0.32 \mathrm{~b}$ & $0.60 \mathrm{~b}$ & $0.89 \mathrm{bc}$ & $1.16 \mathrm{~b}$ \\
S. torvum Sw. & $0.14 \mathrm{a}$ & $2.56 \mathrm{a}$ & $5.55 \mathrm{a}$ & $8.89 \mathrm{a}$ & $10.0 \mathrm{a}$ \\
SMST 1 & $0.11 \mathrm{a}$ & $0.33 \mathrm{~b}$ & $0.62 \mathrm{~b}$ & $1.28 \mathrm{~b}$ & $1.53 \mathrm{~b}$ \\
SMST 2 & $0.08 \mathrm{ab}$ & $0.22 \mathrm{bc}$ & $0.43 \mathrm{bc}$ & $0.60 \mathrm{bc}$ & $0.89 \mathrm{bc}$ \\
SMST 3 & $0.03 \mathrm{~b}$ & $0.15 \mathrm{c}$ & $0.28 \mathrm{c}$ & $0.38 \mathrm{c}$ & $0.45 \mathrm{c}$ \\
SMST 4 & $0.11 \mathrm{a}$ & $0.24 \mathrm{bc}$ & $0.48 \mathrm{bc}$ & $0.80 \mathrm{bc}$ & $1.24 \mathrm{~b}$ \\
SMST 5 & $0.16 \mathrm{a}$ & $0.34 \mathrm{~b}$ & $0.50 \mathrm{bc}$ & $0.69 \mathrm{bc}$ & $0.73 \mathrm{bc}$ \\
\hline
\end{tabular}

Keterangan: Angka yang diikuti huruf sama pada kolom yang sama tidak berbeda nyata pada taraf $5 \%$ berdasarkan uji DMRT.

S. torvum $\mathrm{Sw}$. lebih responsif pada media MStanpa hormon auksin dan sitokinin(Moreira, 2010) sedangkan $S$. melongena tidak dapat tumbuh baik pada media MS tanpa hormon auksin dan sitokinin (Ray, 2011). Penelitian tersebut menunjukkan bahwa dalam kultur in vitro,S. melongena membutuhkan penambahan hormon auksin dan sitokinin, sedangkan $S$. torvum tidak membutuhkan hormon auksin dan sitokinin. Oleh karena itu, performa $S$. torvum $\mathrm{Sw}$. lebih baik dibandingkan S. melongena dan hasil fusi protoplas.

Pada 1 MST, jumlah daun S. torvum Sw. (1.3 helai) telah menunjukkan perbedaan yang nyata dengan semua klon, namun pertumbuhan daun $S$. melongena cv. Dourga (0.2 helai) dan 5 klon lainnya tidak berbeda nyata satu sama lain. Perbedaan pertumbuhan daun antar klon mulai terlihat sejak 2 MST hingga 5 MST. Pada 5 MST, pertambahan jumlah daun $S$. torvum $\mathrm{Sw}$. paling 
tinggi dan sangat berbeda nyata dengan klon lainnya. Klon SMST1, SMST2, SMST4, dan SMST5 tidak berbeda nyata dengan $S$. melongena cv. Dourga dan menempati urutan kedua jumlah daun terbanyak. Pertambahan jumlah daun paling lambat dimiliki oleh klon SMST3 yang berbeda nyata dengan semua klon dan kedua tetua (Tabel $3)$.

Tabel 3. Rata-rata jumlah daun tanaman terungpada keragaan in vitro klon yang diuji umur 1-5 MST

\begin{tabular}{llllll}
\hline Klon & \multicolumn{5}{c}{ Jumlah daun(helai) } \\
\cline { 2 - 6 } & $1 \mathrm{MST}$ & $2 \mathrm{MST}$ & $3 \mathrm{MST}$ & $4 \mathrm{MST}$ & $5 \mathrm{MST}$ \\
\hline S. melongena cv. Dourga & $0.2 \mathrm{~b}$ & $0.8 \mathrm{c}$ & $1.5 \mathrm{bc}$ & $1.8 \mathrm{~b}$ & $2.4 \mathrm{~b}$ \\
Solanum torvum Sw. & $1.3 \mathrm{a}$ & $3.2 \mathrm{a}$ & $4.9 \mathrm{a}$ & $6.0 \mathrm{a}$ & $7.7 \mathrm{a}$ \\
SMST 1 & $0.2 \mathrm{~b}$ & $1.1 \mathrm{bc}$ & $1.6 \mathrm{bc}$ & $2.0 \mathrm{~b}$ & $2.7 \mathrm{~b}$ \\
SMST 2 & $0.2 \mathrm{~b}$ & $1.1 \mathrm{bc}$ & $1.7 \mathrm{~b}$ & $1.8 \mathrm{~b}$ & $2.3 \mathrm{~b}$ \\
SMST 3 & $0.4 \mathrm{~b}$ & $0.7 \mathrm{c}$ & $0.9 \mathrm{c}$ & $0.9 \mathrm{c}$ & $1.4 \mathrm{c}$ \\
SMST 4 & $0.1 \mathrm{~b}$ & $0.8 \mathrm{c}$ & $1.4 \mathrm{bc}$ & $1.8 \mathrm{~b}$ & $1.9 \mathrm{bc}$ \\
SMST 5 & $0.3 \mathrm{~b}$ & $1.4 \mathrm{~b}$ & $1.6 \mathrm{bc}$ & $2.0 \mathrm{~b}$ & $2.2 \mathrm{bc}$ \\
\hline
\end{tabular}

Keterangan: Angka yang diikuti huruf sama pada kolom yang sama tidak berbeda nyata pada taraf $5 \%$ berdasarkan uji DMRT.

Jumlah akar $S$. torvum $\mathrm{Sw}$. berbeda nyata dengan klon hibrida somatik dan memiliki jumlah akar terbanyak pada 1 - 5 MST (Tabel 4). Hal ini sesuai dengan penelitian Moreira (2010) yang menyatakan $S$. torvum menghasilkan pengakaran yang lebih tinggi pada media tanpa penambahan hormon auksin dan sitokinin dibandingkan dengan media yang ditambahkan hormon.Pertumbuhan akar pada klon hibrida somatik mulai terlihat pada 2 MST, namun klon SMST5 baru memiliki akar pada 3 MST. Pada 5 MST, Klon SMST1 (1.6 buah), SMST2 (1.6 buah), SMST3 (1.0 buah), dan
SMST4 (1.4 buah) tidak berbeda nyata satu dengan yang lain dan memiliki jumlah akar di antara $S$. torvum $\mathrm{Sw}$. (6.6 buah) dan $S$. melongena cv. Dourga (0.3 buah). S. melongena cv. Dourga (0.3 buah) memiliki jumlah akar paling sedikit dan tidak berbeda nyata dengan klon SMST5 (0.6 buah) (Tabel 4). Hal ini kemungkinan disebabkan oleh media yang tidak diberi penambahan hormon. Ray (2011) menyatakan S. melongena yang dikulturkan pada media tanpa hormon tidak memiliki kemampuan regenerasi.

Tabel 4. Rata-rata jumlah akar tanaman terung pada keragaan in vitro klon yang diuji umur 1-5 MST

\begin{tabular}{llllll}
\hline Klon & \multicolumn{5}{l}{ Jumlah akar (buah) } \\
\cline { 2 - 6 } & $1 \mathrm{MST}$ & $2 \mathrm{MST}$ & $3 \mathrm{MST}$ & $4 \mathrm{MST}$ & $5 \mathrm{MST}$ \\
\hline S. melongena cv. Dourga & $0.0 \mathrm{~b}$ & $0.3 \mathrm{~cd}$ & $0.3 \mathrm{c}$ & $0.3 \mathrm{c}$ & $0.3 \mathrm{~d}$ \\
S.torvum Sw. & $1.3 \mathrm{a}$ & $5.9 \mathrm{a}$ & $6.5 \mathrm{a}$ & $6.6 \mathrm{a}$ & $6.6 \mathrm{a}$ \\
SMST 1 & $0.0 \mathrm{~b}$ & $1.1 \mathrm{~b}$ & $1.3 \mathrm{~b}$ & $1.4 \mathrm{~b}$ & $1.6 \mathrm{~b}$ \\
SMST 2 & $0.0 \mathrm{~b}$ & $0.7 \mathrm{bc}$ & $1.6 \mathrm{~b}$ & $1.6 \mathrm{~b}$ & $1.6 \mathrm{~b}$ \\
SMST 3 & $0.0 \mathrm{~b}$ & $0.4 \mathrm{~cd}$ & $0.5 \mathrm{c}$ & $0.6 \mathrm{c}$ & $1.0 \mathrm{bc}$ \\
SMST 4 & $0.0 \mathrm{~b}$ & $0.4 \mathrm{~cd}$ & $1.2 \mathrm{~b}$ & $1.3 \mathrm{~b}$ & $1.4 \mathrm{~b}$ \\
SMST 5 & $0.0 \mathrm{~b}$ & $0.0 \mathrm{~d}$ & $0.3 \mathrm{c}$ & $0.5 \mathrm{c}$ & $0.6 \mathrm{~cd}$ \\
\hline
\end{tabular}

Keterangan: Angka yang diikuti huruf sama pada kolom yang sama tidak berbeda nyata pada taraf $5 \%$ berdasarkan uji DMRT.

Pertumbuhan panjang akar S. torvum Sw. terjadi sangat cepat pada 2 MST, sedangkan pada 3-5 MST tidak terjadi penambahan panjang akar yang signifikan (Tabel 5). Hal ini berbeda dengan pertumbuhan akar $S$. melongena cv. Dourga dan klon hibrida somatik yang secara umum terlihat cepat pada 3 MST.

Pada 4 MST, hanya klon SMST5 yang pertambahan panjang akarnya masih signifikan
(Tabel 5). Panjang akar S. torvum Sw. $(5.91 \mathrm{~cm})$ sangat berbeda nyata dengan semua klon hibrida somatik dan memiliki akar terpanjang pada 5 MST. S. melongena cv. Dourga $(1.00 \mathrm{~cm})$ memiliki akar terpendek dan tidak berbeda nyata dengan klon SMST2 $(1.64 \mathrm{~cm})$, SMST3 $(1.11 \mathrm{~cm})$, SMST4 $(1.99 \mathrm{~cm})$, SMST5 $(1.09 \mathrm{~cm})$, namun berbeda nyata dengan klon SMST1 $(2.37 \mathrm{~cm})$. 
Tabel 5. Rata-rata panjang akar tanaman terungpada keragaan in vitro klon yang diuji umur 1-5 MST

\begin{tabular}{llllll}
\hline Klon & \multicolumn{5}{c}{ Panjang akar $(\mathrm{cm})$} \\
\cline { 2 - 6 } & $1 \mathrm{MST}$ & $2 \mathrm{MST}$ & $3 \mathrm{MST}$ & $4 \mathrm{MST}$ & $5 \mathrm{MST}$ \\
\hline S. melongena cv.Dourga & $0.00 \mathrm{~b}$ & $0.13 \mathrm{bc}$ & $0.82 \mathrm{bc}$ & $0.92 \mathrm{~b}$ & $1.00 \mathrm{c}$ \\
Solanum torvum Sw. & $1.23 \mathrm{a}$ & $5.28 \mathrm{a}$ & $5.91 \mathrm{a}$ & $5.91 \mathrm{a}$ & $5.91 \mathrm{a}$ \\
SMST1 & $0.00 \mathrm{~b}$ & $0.32 \mathrm{~b}$ & $1.47 \mathrm{~b}$ & $2.07 \mathrm{~b}$ & $2.37 \mathrm{~b}$ \\
SMST2 & $0.00 \mathrm{~b}$ & $0.14 \mathrm{bc}$ & $0.915 \mathrm{~b}$ & $1.415 \mathrm{~b}$ & $1.64 \mathrm{bc}$ \\
SMST3 & $0.00 \mathrm{~b}$ & $0.13 \mathrm{bc}$ & $0.63 \mathrm{bc}$ & $0.86 \mathrm{~b}$ & $1.11 \mathrm{bc}$ \\
SMST4 & $0.00 \mathrm{~b}$ & $0.14 \mathrm{bc}$ & $1.25 \mathrm{~b}$ & $1.63 \mathrm{~b}$ & $1.99 \mathrm{bc}$ \\
SMST5 & $0.00 \mathrm{~b}$ & $0.00 \mathrm{c}$ & $0.095 \mathrm{c}$ & $0.95 \mathrm{~b}$ & $1.09 \mathrm{bc}$ \\
\hline
\end{tabular}

Keterangan: Angka yang diikuti huruf sama pada kolom yang sama tidak berbeda nyata pada taraf $5 \%$ berdasarkan uji DMRT.

S. torvum Sw. memiliki jumlah buku terbanyak dan berbeda nyata dengan klon lainnya (Tabel 6). Klon SMST2 (3.0 buah) merupakan klon hibrida dengan jumlah buku terbanyak dan berbeda nyata dengan klon SMST5 (1.5 buah) yang memiliki jumlah buku paling sedikit.

Tabel 6. Rata-rata jumlah buku klon yang diuji pada kondisi in vitroumur 5 MST

\begin{tabular}{lc}
\hline Klon & Jumlah buku (buah) \\
\hline S. melongena cv. Dourga & $2.3 \mathrm{bcd}$ \\
S. torvum Sw. & $6.7 \mathrm{a}$ \\
SMST1 & $2.4 \mathrm{bcd}$ \\
SMST2 & $3.0 \mathrm{~b}$ \\
SMST3 & $1.7 \mathrm{~cd}$ \\
SMST4 & $2.5 \mathrm{bc}$ \\
SMST5 & $1.5 \mathrm{~d}$ \\
\hline
\end{tabular}

Keterangan: Angka yang diikuti huruf sama pada kolom yang sama tidak berbeda nyata pada taraf $5 \%$ berdasarkan uji DMRT.

Pada kondisi in vitro, keragaan morfologi tanaman secara kualitatif memperlihatkan adanya perbedaan yang jelas antara klon SMST5 dengan kultivar pembanding maupun klon lainnya. Klon SMST5 memiliki warna daun yang berbeda dengan klon lainnya. Daun klon SMST5 berwarna hijau muda di bagian tengah dan berwarna putih di sepanjang tepi daunnya (variegata), sedangkan klon lainnya dan kultivar pembanding memiliki daun berwarna hijau di seluruh permukaannya (Gambar 1).
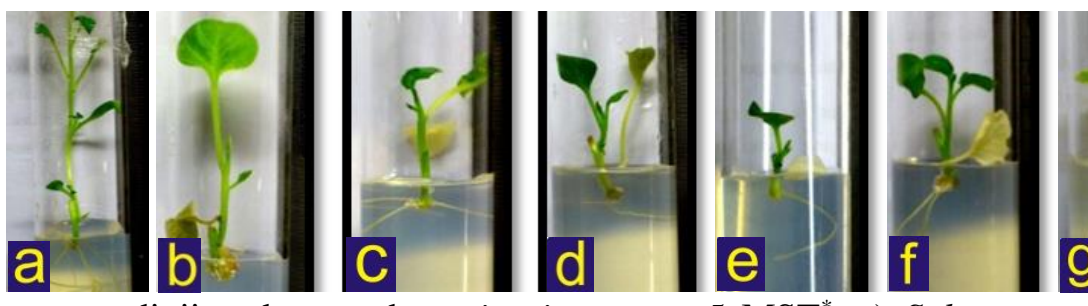

Gambar 1. Klon yang diuji pada percobaan in vitro umur 5 MST*. a) Solanum torvum Sw., b)Solanum melongena cv. Dourga, c) SMST1, d) SMST2, e) SMST3, f) SMST4, g) SMST5.

\section{Keragaan Fenotipik Tanaman in Vivo}

Keragaan fenotipik yang diamati pada percobaan in vivo menunjukkan perbedaan sangat nyata hanya pada peubah tinggi tanaman dan jumlah duri pada permukaan atas daun. Peubah tinggi tanaman pada klon-klon yang diuji menunjukkan perbedaan yang nyata pada umur 1 MST, 4 MST, dan 5 MST. Pada umur 2 MST dan 3 MST, peubah tinggi tanaman tidak menunjukkan perbedaan yang nyata berdasarkan uji statistik (Tabel 7). 
Tabel 7. Rekapitulasi uji $\mathrm{F}$ dari peubah vegetatif yang diamati pada keragaan tanaman terungin vivo klon yang diuji

\begin{tabular}{llllll}
\hline Peubah vegetatif & \multicolumn{5}{c}{ Klon } \\
\cline { 2 - 6 } & 1 MST & 2 MST & 3 MST & 4 MST & 5 MST \\
\hline Tinggi tanaman & $*$ & tn & tn & $* *$ & $* *$ \\
Jumlah daun & $*$ & $*$ & tn & tn & tn \\
Panjang daun & - & - & - & - & tn \\
Panjang tangkai daun & - & - & - & - & tn \\
Jumlah duri pada permukaan atas daun & - & - & - & - & $* *$ \\
\hline
\end{tabular}

Keterangan; *: berpengaruh nyata pada uji $\mathrm{F}$ taraf $5 \%,{ }^{*}$ : berpengaruh sangat nyata pada uji $\mathrm{F}$ taraf $1 \%$, tn: tidak berpengaruh nyata pada uji $\mathrm{F}$ taraf 5\%, - : pengamatan tidak dilakukan.

Pada 5 MST, SMST4 $(24.61 \quad \mathrm{~cm})$ menunjukkan pertumbuhan tertinggi dan tidak berbeda nyata dengan SMST2 $(23.06 \mathrm{~cm})$. SMST1 $(18.90 \mathrm{~cm})$ dan SMST3 $(20.56 \mathrm{~cm})$ tidak menunjukkan perbedaan yang nyata, dan memiliki tinggi di bawah SMST2. Pertumbuhan terendah dimiliki oleh $S$. torvum $\mathrm{Sw}$. $(14.67 \mathrm{~cm})$ yang tidak memiliki perbedaan nyata dengan S. melongena cv. Dourga $(13.00 \mathrm{~cm})$ (Tabel 8). Perbedaan tinggi yang signifikan pada 4-5 MST mengindikasikan adanya kemampuan tumbuh yang berbeda antar klon. Klon SMST2 dan SMST4 lebih tinggi dan berbeda nyata dari kedua tetua pembanding.

Tabel 8. Rata-rata tinggi tanamanterung klon yang diuji pada kondisi in vivo umur 1-5 MST

\begin{tabular}{lllcll}
\hline \multirow{2}{*}{ Klon } & \multicolumn{5}{c}{ Tinggi tanaman $(\mathrm{cm})$} \\
\cline { 2 - 6 } & $1 \mathrm{MST}$ & $2 \mathrm{MST}$ & $3 \mathrm{MST}$ & $4 \mathrm{MST}$ & $5 \mathrm{MST}$ \\
\hline S. melongena & $6.91 \mathrm{a}$ & 7.23 & 9.05 & $10.80 \mathrm{~b}$ & $13.00 \mathrm{~b}$ \\
S. torvum Sw. & $2.20 \mathrm{c}$ & 4.60 & 7.33 & $10.50 \mathrm{~b}$ & $14.67 \mathrm{~b}$ \\
SMST1 & $4.22 \mathrm{abc}$ & 4.83 & 8.85 & $13.20 \mathrm{ab}$ & $18.90 \mathrm{ab}$ \\
SMST2 & $6.54 \mathrm{ab}$ & 7.94 & 12.28 & $17.00 \mathrm{a}$ & $23.06 \mathrm{a}$ \\
SMST3 & $4.76 \mathrm{abc}$ & 6.21 & 10.33 & $14.67 \mathrm{ab}$ & $20.56 \mathrm{ab}$ \\
SMST4 & $3.60 \mathrm{bc}$ & 5.54 & 11.41 & $17.5 \mathrm{a}$ & $24.61 \mathrm{a}$ \\
\hline
\end{tabular}

Keterangan: Angka yang diikuti huruf sama pada kolom yang sama tidak berbeda nyata pada taraf $5 \%$ berdasarkan uji DMRT.

Dari enam klon yang diamati, peubah duri menunjukkan perbedaan yang signifikan berdasarkan uji statistik. Jumlah duri pada daun $S$. torvum Sw. (12.33 buah) berbeda nyata lebih banyak dari keempat klon hibrida somatik. Sedangkan S. melongena cv. Dourga (0.00 buah) tidak memiliki duri pada daunnya (Tabel 9).

Morfologi batang meliputi pertumbuhan batang, warna batang, dan keberadaan duri pada batang. Pertumbuhan batang tanaman terung ada yang tegak lurus, intermediate, dan lemah (tidak tegak lurus) (IBPGR,1990). Pertumbuhan batang $S$. melongena cv. Dourga dan S. torvum Sw. menunjukkan pertumbuhan batang yang tegak (upright). Fusi protoplas kedua tetua ini menghasilkan klon dengan pertumbuhan batang yang tegak pula.

Tabel 9. Rata-rata jumlah duri permukaan daun klon tanaman terung yang diuji pada kondisi in vivo 5 MST

\begin{tabular}{lc}
\hline Klon & Jumlah duri permukaan daun \\
\hline S. melongena cv. Dourga & $0.00 \mathrm{c}$ \\
S. torvum Sw. & $12.33 \mathrm{a}$ \\
SMST1 & $7.93 \mathrm{~b}$ \\
SMST2 & $7.99 \mathrm{~b}$ \\
SMST3 & $9.64 \mathrm{~b}$ \\
SMST4 & $7.67 \mathrm{~b}$
\end{tabular}

Keterangan: Angka yang diikuti huruf sama pada kolom yang sama tidak berbeda nyata pada taraf $5 \%$ berdasarkan uji DMRT. 
Tabel 10. Matrik perbedaan morfologi tanaman terung pada percobaan in vivo

\begin{tabular}{|c|c|c|c|c|c|c|}
\hline \multirow[t]{2}{*}{ Karakter morfologi } & \multicolumn{6}{|c|}{ Klon } \\
\hline & S. torvum & $\begin{array}{l}\text { S. melongena cv. } \\
\text { Dourga }\end{array}$ & SMST1 & SMST2 & $\begin{array}{c}\text { SMST } \\
3 \\
\end{array}$ & SMST4 \\
\hline $\begin{array}{l}\text { Pertumbuhan batang } \\
\text { 1. Upright (tegak) } \\
\text { 2. Intermediete } \\
\text { 3. Prostate (rebah) }\end{array}$ & $\mathrm{X}$ & $\mathrm{X}$ & $\mathrm{X}$ & $\mathrm{X}$ & $\mathrm{X}$ & $\mathrm{X}$ \\
\hline $\begin{array}{l}\text { Warna batang } \\
\text { 1. Hijau }\end{array}$ & & $\mathrm{X}$ & & & & \\
\hline $\begin{array}{l}\text { 2. Hijau keunguan } \\
\text { 3. Ungu }\end{array}$ & $\mathrm{X}$ & & $\mathrm{X}$ & $\mathrm{X}$ & $\mathrm{X}$ & $\mathrm{X}$ \\
\hline Tinggi tanaman & & & & & & \\
\hline $\begin{array}{l}\text { 1. Sangat pendek } \\
\text { 2. Pendek } \\
\text { 3. Sedang } \\
\text { 4. Tinggi }\end{array}$ & $\mathrm{X}$ & $\mathrm{X}$ & $\mathrm{X}$ & $\mathrm{X}$ & $\mathrm{X}$ & $\mathrm{X}$ \\
\hline $\begin{array}{l}\text { Warna petiola } \\
\text { 1. Hijau }\end{array}$ & & $\mathrm{X}$ & & & & \\
\hline $\begin{array}{l}\text { 2. Hijau keunguan } \\
\text { 3. Ungu }\end{array}$ & $\mathrm{X}$ & & $\mathrm{X}$ & $\mathrm{X}$ & $\mathrm{X}$ & $\mathrm{X}$ \\
\hline $\begin{array}{l}\text { Panjang daun } \\
1 . \text { Pendek }\end{array}$ & & & $\mathrm{X}$ & & $x$ & \\
\hline $\begin{array}{l}\text { 2. Sedang } \\
\text { 3. Panjang }\end{array}$ & $\mathrm{X}$ & $\mathrm{X}$ & & $\mathrm{X}$ & $\Lambda$ & $\mathrm{X}$ \\
\hline Panjang tangkai daun & & & & & & \\
\hline $\begin{array}{l}\text { 1. Pendek } \\
\text { 2. Sedang } \\
\text { 3. Panjang }\end{array}$ & $\mathrm{X}$ & $\mathrm{X}$ & $\mathrm{X}$ & $\mathrm{X}$ & $\mathrm{X}$ & $\mathrm{X}$ \\
\hline Leaf blade lobing & & & & & & \\
\hline $\begin{array}{l}\text { 1. Sangat lemah } \\
\text { 2. Lemah } \\
\text { 3. Sedang }\end{array}$ & & $\mathrm{X}$ & & & & \\
\hline $\begin{array}{l}\text { 4. Kuat } \\
\text { 5. Sangat kuat }\end{array}$ & $\mathrm{X}$ & & $\mathrm{X}$ & $\mathrm{X}$ & $\mathrm{X}$ & $\mathrm{X}$ \\
\hline $\begin{array}{l}\text { Duri Permukaan atas } \\
\text { daun } \\
\text { 1. Tidak ada } \\
\text { 2. Sangat sedikit }\end{array}$ & & $\mathrm{X}$ & & & & \\
\hline 3. Sedikit & & & $\mathrm{X}$ & $\mathrm{X}$ & $\mathrm{X}$ & $\mathrm{X}$ \\
\hline $\begin{array}{l}\text { 4. Sedang } \\
\text { 5. Banyak } \\
\text { 6. Sangat banyak }\end{array}$ & $\mathrm{X}$ & & & & & \\
\hline Warna kelopak bunga & & & & & & \\
\hline 1. Putih & $\mathrm{X}$ & & & & & \\
\hline $\begin{array}{l}\text { 2. Ungu } \\
\text { 3. Tidak berbunga }\end{array}$ & & $\mathrm{X}$ & $\mathrm{X}$ & $\mathrm{X}$ & $\mathrm{X}$ & $\mathrm{X}$ \\
\hline
\end{tabular}

Pada umur 5 MST, S. melongena cv. Dourga memiliki warna batang hijau terang di seluruh permukaan batangnya dan ditumbuhi rambut-rambut yang sangat halus. Pada umur yang sama, $S$. torvum $\mathrm{Sw}$. memiliki batang yang berwarna hijau keunguan dan ditumbuhi rambutrambut halus yang lebih jelas terlihat dibandingkan $S$. melongena cv. Dourga. Fusi protoplas kedua tetua ini menghasilkan klon SMST1, SMST2, SMST3, dan SMST4 yang memiliki warna batang menyerupai $S$. torvum Sw. (Tabel 10).

Tangkai daun S. melongena cv. Dourga pada umur 5 MST berwarna hijau, sedangkan tangkai daun $S$. torvum $\mathrm{Sw}$. berwarna hijau keunguan. Fusi protoplas kedua tetua ini menghasilkan klon SMST1, SMST2, SMST3, dan SMST4 yang memiliki tangkai daun menyerupai $S$. torvum Sw., yakni hijau keunguan. Permukaan daun pada S. melongena 
cv. Dourga bergelombang dan tidak ditumbuhi duri-duri tajam yang tersebar dipermukaannya. Keempat klon yang diuji menunjukkan bentuk permukaan daun rata dan ditumbuhi duri-duri tajam yang tersebar di permukaannya. Keempat klon yang diuji menunjukkan bentuk permukaan daun rata dan ditumbuhi duri-duri tajam (Tabel 10).

Tanaman terung memiliki daun berbentuk bulat telur dengan ujung meruncing dan pangkal berbentuk setengah lingkaran, sedangkan tepi daun bergelombang dengan ujung yang bermacam-macam, mulai dari yang tumpul hingga meruncing. Terdapat lima kelompok pembagian bentuk lobus daun (leaf blade lobing), yaitu sangat lemah (tepi daun rata tidak bergelombang), lemah (sedikit bergelombang), intermediete (terlihat jelas bergelombang namun ujung belum runcing), kuat (terlihat menjari dan ujung runcing), dan sangat kuat (tepi daun menjari dan terlihat seperti membentuk anak daun) (IBPGR, 1990). Pada umur 5 MST, lobus daun S. melongena cv. Dourga masuk dalam kategori lemah (tepi daun terlihat sedikit bergelombang), sedangkan $S$. torvum Sw. masuk dalam kategori sangat kuat, yakni tepi daun terlihat seperti membentuk anak daun. Fusi protoplas kedua tetua ini menghasilkan klon SMST1, SMST2, SMST3, dan SMST4 yang memiliki bentuk lobus daun menjari dan ujung meruncing (kategori kuat) (Tabel 10).

Hasil pengamatan sekunder yang dilakukan terhadap pembungaan klon-klon hibrida somatik memperlihatkan bahwa klon SMST2 dan SMST3 berhasil berbunga dengan bentuk dan warna kelopak yang menyerupai $S$. melongena cv. Dourga, akan tetapi tumbuh bergerombol menyerupai $S$. torvum Sw ( Tabel 10). Adapun klon SMST1 dan SMST4 pada waktu yang sama belum menunjukkan tanda-tanda pembungaan.
Potensi genetik yang dapat dilihat dari bunga yang tumbuh menggerombol pada hibrida somatik ini adalah kemungkinan untuk mendapatkan tanaman terung dengan jumlah buah yang banyak pada satu tanaman. Sihachakr et. al. (1994) juga telah melakukan fusi protoplas $S$. melongena $\mathrm{L}$. dengan S. torvum Sw. dan mendapatkan hibrida somatik yang memiliki karakter morfologi batang dan daun menyerupai $S$. torvum Sw., sedangkan bunganya menyerupai bunga $S$. melongena $\mathrm{L}$.

\section{Analisis Gerombol}

Analisis gerombol dilakukan berdasarkan keragaan fenotipik tanaman di lapangan yang terdiri dari delapan karakter, yaitu tinggi tanaman, warna batang, jumlah daun, panjang daun, panjang tangkai daun, jumlah duri pada permukaan daun, warna tangkai daun, dan bentuk tepi daun. Kekerabatan tanaman dalam pengelompokan ini didasarkan pada karakter yang dimiliki oleh masing-masing tanaman dan dibuat skor untuk analisis gerombol. Dendogram menunjukkan kekerabatan hubungan antar individu tanaman. Semakin dekat jarak yang satu dengan yang lain, maka semakin dekat pula kekerabatannya. Berdasarkan hasil analisis gerombol, klon-klon tersebut dapat dikelompokkan menjadi dua kelompok menurut jarak kedekatan (similarity) dengan persentase kemiripan > 80\% (Tabel 11). Hasil pengelompokan pada kekerabatan > 80\% menunjukkan kelompok satu ditempati oleh $S$. torvum Sw. dan empat klon hasil fusi (SMST1, SMST2, SMST3, dan SMST4), sedangkan kelompok dua hanya ditempati oleh $S$. melongena cv. Dourga. Dendogram (Gambar 2) menunjukkan bahwa keempat klon yang diamati memiliki keragaan fenotipik yang lebih menyerupai $S$. torvum $\mathrm{Sw}$.

Tabel 11. Pengelompokan tanaman dengan kekerabatan lebih dari $80 \%$

\begin{tabular}{ll}
\hline Kelompok & Jenis klon \\
\hline I & Solanum torvum Sw, SMST1, SMST2, SMST3, SMST4 \\
II & Solanum melongena cv. Dourga \\
\hline
\end{tabular}




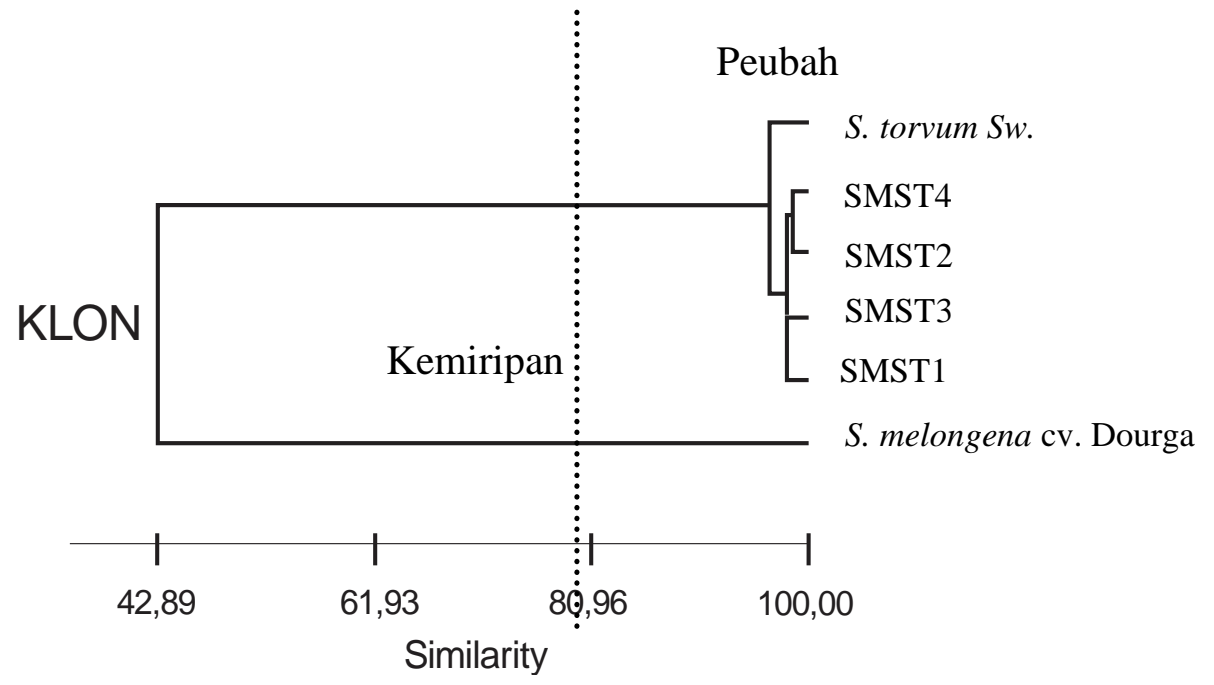

Gambar 2. Dendogram klon berdasarkan karakter kualitatif dan kuantitatif

\section{KESIMPULAN}

Pada percobaan in vitro, keragaan fenotipik semua peubah pada klon-klon yang diuji menunjukkan kemiripan dengan $S$. melongena $\mathrm{cv}$. Dourga dan berbeda nyata dengan $S$. torvum $\mathrm{Sw}$. Pada percobaan in vitro, klon SMST1, SMST2, dan SMST4 memiliki kemampuan tumbuh lebih baik dari klon SMST3 dan SMST5. Pada percobaan in vivo, klon-klon yang diuji menunjukkan perbedaan yang nyata pada peubah tinggi tanaman dan jumlah duri pada permukaan daun, sedangkan pada peubah jumlah daun, panjang daun, dan panjang tangkai daun, klonklon yang diuji tidak menunjukkan perbedaan yang signifikan dengan kultivar pembanding. Hasil analisis gerombol memperlihatkan bahwa klon-klon yang diuji memiliki kekerabatan yang lebih dekat kepada $S$. torvum Sw. dibandingkan dengan $S$. melongena cv. Dourga.

\section{DAFTAR PUSTAKA}

Budi EL. 2002. Evaluasi ketahanan nomor-nomor tanaman hasil fusi protoplas antara terung (Solanum melongena cv. Dourga) dengan terung pipit (Solanum torvum CN2) terhadap penyakit layu bakteri Rastolnia solanacearum [Skripsi]. Bogor (ID): Institut Pertanian Bogor. 27 hlm.

Collonier C, Mulya K, Fock I, Mariska I, Servaes A, Vedel F, Yakovlev SS, Souvannavong V, Ducreux G, Sihachakr D. 2001. Source of resistance against Rastolnia solanacearumin fertile somatic hybrids of eggplant (Solanum melongena L.) with Solanum aethiopicum L. Plant Science 160:301-313.

Husni A. 2002. Studi regenerasi protoplas tanaman terung (Solanum melongena L.) dan ketahanan regeneran terhadap penyakit bakteri layu (Rastolnia solanacearum) [Tesis]. Bogor (ID): Institut Pertanian Bogor. 59 hal.

Husni A, Mariska I, Hobir. 2004. Fusi protoplas dan regenerasi hasil fusi antara Solanum melongena dan Solanum torvum Sw. Bioteknologi Pertanian 9(1): 1-7.

Husni A. 2010. Fusi Interspesies antara Jeruk Siam Simadu (Citrus nobilis Lour.) dengan Mandarin Satsuma (Citrus unshiu Marc.) [Disertasi]. Bogor (ID): Institut Pertanian Bogor. 149 hal.

[IBPGR] International Board for Plant Genetic Resources. 1990. Descriptors for Eggplant. Rome: IBPR pr. $23 \mathrm{hlm}$.

Kallo. 1986. Vegetable Breeding volume II. Florida: CRC Inc. $2122 \mathrm{hlm}$.

Mariska I, Husni A. 2006. Perbaikan sifat genotipe melalui fusi protoplas pada tanaman lada, nilam, dan terung. Litbang Pertanian 25(2):55-60.

Morel G, Wetmore RH. 1951. Fern callus tissue culture. Am. J. Bot 38:141-143.

Moreira CB, Lima SS, Esquibel MA, Sato A. 2010. Solasodine acumulation in regenerated plants of Solanum torvum Sw. Revista brasileira de plantas 
medicinais12(1). [diunduh 2012 Sep 11]. Tersedia pada:http://www.scielo.br/

Murashige T, Skoog F. 1962. A revised medium for rapid growth and bioassays with tobacco tissue cultures. Physiologia Pantarum 15: 473-497

Ray PB, Hasan L, Sarker SK. 2011. In vitro cultivation and regeneration of Solanum melongena $($ L.) using stem, root and leaf explants. Nepal J. Biotech 1(1): 49-54.

Saputra D. 2002. Evaluasi ketahanan hibrid somatik Solanum melongena dengan Solanum aethiopicum dan turunannya terhadap penyakit layu bakteri [Skripsi]. Bogor (ID): Institut Pertanian Bogor. 38 hlm.
Sihachakr D, Daunay MC, Serraf I, Chaput MH, Mussio I, Haicour R, Rossignol L, Ducreux G. 1994. Somatic hybridization of eggplant (Solanum melongena L.) with its close and wild relatives. P. 255-278. In Bajaj YPS (Eds.). Somatic Hybridization in Crop Improvement I. Biotechnology in Agriculture and Forestry Vol.27. SpringerVeriag Berlin Heidelberg.

Tahat MM, Sijam K. 2010. Rastolnia solanacearum: the bacterial wilt causal agent. Plant Science 9(7):385-393.

Wijayakusuma HMH. 2004. Penyembuhan Dengan Terung. Jakarta (ID): Pustaka Populer Obor. $76 \mathrm{hlm}$. 